Scientia Militaria vol 44, no 1, 2016, pp 209-223. doi:10.5787/44-1-1168

\title{
Politics Under Conditions of War: the effect of the War Measures Acts on Political Struggles within the South African Mine Workers' Union, 1939-1947
}

\author{
Wessel Visser ${ }^{\bullet}$
}

\begin{abstract}
The South African Mine Workers' Union, or MWU, was one of the most prominent white trade unions of $20^{\text {th }}$-century South Africa and active in one of the country's key industries, namely gold mining. In the aftermath of the violent 1922 strike, the union's executive was bureaucratised, which left the MWU vulnerable to corruption and maladministration. This gave rise to a protracted struggle for control of the union's executive. In the 1930s and 1940s the strife within MWU ranks became entangled with the national struggle for political hegemony between the National Party and the United Party, as well as Afrikaner nationalism. At the outbreak of World War II the Smuts cabinet armed the state under War Measures' Acts, which entitled it to a range of arbitrary powers, including powers to control strategic minerals, such as gold, and to curb industrial unrest. Naturally, the War Measures' Acts had a significant effect on the doings of the MWU - in particular the struggle for political control of its executive. The struggle involved three official commissions of inquiry into the affairs of the MWU, two mining strikes and numerous court actions between the two competing factions within its ranks. As a result of the stipulations of the War Measures' Acts pertaining to the mining industry, as well as those of the MWU constitution, a political impasse to solve the issue of democratic elections in the union arose. Therefore the War Measures' Acts still had legal repercussions for the union three years after the cessation of hostilities. As such, the War Measures' Acts ${ }^{1}$ influenced politics and elections in the MWU as late as 1948.
\end{abstract}

Keywords: South Africa, Second World War, labour movements

\section{Introduction}

According to the famous French Annales School historian, Fernand Braudel, as quoted by JM Winter, war cannot be understood if abstracted from non-military developments, which both affect it and are affected by it. ${ }^{2}$ Albert Grundlingh also argues that scholars in the field of war and society seek to place warfare in its total historical milieu. They share a common interest in war as an agent of social change and in the socio-political repercussions of military service ${ }^{3}$, therefore also focusing on aspects of warfare beyond the actual theatres of war. Already in the $20^{\text {th }}$ century historians in Britain began to investigate themes such as the economic, social, and administrative problems of a nation at war, the effect of economic and social change on the waging of war and its destructiveness, problems to produce and supply men, munitions and goods essential to the war effort, sources of war taxation, etc. ${ }^{4}$

Department of History, University of Stellenbosch. I am indebted to my colleagues, Bill Nasson and Albert Grundlingh, for providing valuable perspectives and sources on war and society. Research for this article was made possible by funding from the National Research Foundation. 
In 1978, Mark Stein published an essay in South Africa on Max Gordon, who became the secretary of the African Laundry Workers Union in Johannesburg. Stein explains how the emergency regulations of the War Measures' Acts promulgated by the South African government after the outbreak of World War II, curtailed trade union activities. Gordon, a communist, was suspected of subversive activities and was interned from 1940 to $1941 . .^{5}$ Recently, post-graduate studies at South African universities also began to focus on war-related issues, which profoundly affected civilian populations of societies at war. For instance, Yolandi Albertyn investigated the availability of foodstuffs on domestic markets and food control in South Africa during World War II. ${ }^{6}$

The study on which this article is based, investigated the influence of the War Measures' Acts during World War II in the gold mining industry, and how these measures affected labour politics in the war years and in the years immediately after the war, particularly in the South African Mine Workers' Union.

\section{The Mine Workers' Union in historical context}

Originally founded on 22 June 1902 in Johannesburg as the Transvaal Miners' Association, or TMA, this union became prominent for its militant stance in the great industrial strikes during the first two decades of the existence of the Union of South Africa. After the 1913 strike, the TMA was renamed the (South African) Mine Workers' Union or MWU. ${ }^{7}$ The year 1922 saw the biggest and bloodiest industrial upheaval in South African labour history. It entailed a violent three-month strike, which was eventually suppressed by government forces. ${ }^{8}$ In order to prevent similar violent clashes between labour, capital and the state in future, the government implemented the Industrial Conciliation Act of 1924. On the one hand, this Act gave unionised white workers a secure position against undercutting in industry from any quarter, while on the other hand,it also helped mine management by the obstacles it placed in the way of precipitating strike action. With this Act, as well as by the introduction of the Mines and Works Amendment (or 'Colour Bar') Act of 1926, government was able to wean white labour away from militant industrial action by promoting a policy of job reservation in skilled trades and simultaneously to appease possible resentment of the skilled white miner about cheap unskilled black labour. ${ }^{9}$

Davies and Yudelman argue that labour legislation in the post-1922 period effectively led to the incorporation, institutionalisation and bureaucratisation of white unions within state structures. Organised white labour lost its power to use strikes as an effective political and economic weapon, and accepted collective bargaining and civilised labour policy in exchange for compliance with state-controlled labour structures. Thus, the MWU was to become a docile, pro-government union. Within union structures, power passed into the hands of a bureaucracy of permanent and salaried trade union officials. Concomitantly, the rank and file membership became increasingly alienated from union leaders and apathetic towards unions in general. ${ }^{10}$ After the 1922 strike, the leadership of the MWU went into the hands of an executive which, through financial maladministration, neglected the interests of the mine workers who were not always familiar with the true nature, objectives and functioning of trade unionism. ${ }^{11}$

Many historians regard the 1930s and 1940s as the years when Afrikaner nationalism peaked. In this period, the MWU became embroiled in the intense and sometimes fierce struggle for political hegemony between DF Malan's National Party (NP) and Gen. Jan Smuts's newly founded United Party (UP). For Afrikaner political and cultural leaders within the NP, as well as the UP with its ally, the South 
African Labour Party (SALP), the densely populated mining constituencies of the Witwatersrand became crucial political battlegrounds in general elections. ${ }^{12}$

Already World War I saw a continuation of the increasing Afrikanerisation of the white labour contingent on the Witwatersrand gold mines. At the outbreak of the war in 1914 thousands of loyal English-speaking miners volunteered for the British war effort, thus creating a shortage of white miners. Many Afrikaners who did not share these pro-war sentiments took their places on the mines. By 1916, they comprised the majority of white miners when the ratio of Afrikaner to immigrant workers on the mines was $75 \%$ to $25 \% .{ }^{13}$ These figures reflect the gradual transformation of the white working class on the mines into one that consisted predominantly of Afrikaners. ${ }^{14}$ By 1936, for instance, Afrikaners constituted $90 \%$ of the MWU's 12000 members, but they had virtually no representation on the union's executive and therefore no say in running its affairs. Consequently, therefore, with the battle for political power in the public domain, a bitter and protracted struggle was waged for twelve years between Afrikaner Nationalists in the NP and their foes in the UP - SALP alliance for political control of the MWU. ${ }^{15}$

In October 1936, young middle-class Afrikaner intellectuals under the leadership of Dr. Albert Hertzog, son of the founder of the NP, Gen. JBM Hertzog, established the Nasionale Raad van Trustees, or NRT. ${ }^{16}$ The main objective of the NRT was to organise the Afrikaner working class under the wing of a broader Afrikanerdom. Consequently, the Afrikanerbond van Mynwerkers, or ABM, was established in November 1936 as a counter-union to the MWU. ${ }^{17}$ For Afrikaner culture brokers, Afrikaner miners had to be weaned from possible susceptibility to "alien influences" in institutions such as the MWU and the SALP, which were dominated by English speakers. ${ }^{18}$ There were also union-related motives behind the formation of the ABM. Miners held many grievances and reputed grievances regarding the general working conditions on the mines. As the only officially recognised union, the MWU was the sole conduit through which such grievances could be aired. However, the union was weak and inefficient, and in the eyes of the workers, it made no concrete efforts to improve their working conditions and further their interests. The general feeling was that the MWU executive collaborated with the Chamber of Mines, which represented the interests of the mining houses, to keep the economic standard of the miners at a low level.

The Chamber's practice, supported by the MWU, of actively recruiting skilled labour abroad rather than employing Afrikaners, was regarded as a gross form of economic repression. Profitable and less dangerous work was allegedly reserved for non-Afrikaners. Virtually all less profitable underground work was done by Afrikaner miners, who lived in extreme poverty. Under these conditions many miners became easy victims of phthisis, which shortened their life expectancy substantially. In addition, the pension fund for underground miners was inadequate, and the MWU executive allegedly did nothing to improve the situation. ${ }^{19}$

Many aspects of the management of the MWU were also seriously questioned. Under the leadership of Charles Harris, the general secretary, the MWU was "blatantly" corrupt and autocratic, and was perceived to be in league with the Chamber of Mines. Incompetent union officials were appointed in management positions, which they allegedly also obtained irregularly. Furthermore, there were complaints about the manipulation of elections for union officials, ballot rigging, and illegal representation on the MWU general council by unauthorised outsiders. ${ }^{20}$ In an effort to thwart the ABM's challenge to its existence, the MWU pressured the Chamber of Mines to reintroduce the closed shop agreement in June 1937 (the agreement was originally annulled by the Chamber after the 1922 strike). 
This step had serious consequences for the ABM, the practical implications of the agreement being that white underground miners were forced to join the MWU as the only union officially recognised by the Chamber and to pay their union dues. ${ }^{21}$

Although the ABM was theoretically disbanded in June 1937, its adherents were still determined to fight Charles Harris and the officials of the MWU. ${ }^{22}$ In October 1938, a new organisation, the Reformers' Organisation, or Reformers, was founded within the MWU and with the NRT's omnipotent Albert Hertzog as chairperson. Its most important objective was to reform the MWU constitutionally from within and to transform it into an Afrikaans-speaking Christian-national trade union by taking over the MWU management. ${ }^{23}$

\section{The MWU and the War Measures Acts of World War II}

The political stirrings within the MWU were profoundly influenced by South Africa's entrance into World War II. Gen. Hertzog's reign as South African prime minister came to a dramatic end in September 1939. He lost a motion by Gen. Smuts in Parliament by 80 votes to 67 that South Africa sever relations with Germany and join the Allied war effort. Consequently, Hertzog resigned from politics and Smuts became the new prime minister. ${ }^{24}$ After the outbreak of the war, Britain issued the Emergency Powers Act and Defence Regulations. Under the Essential Works Order (March 1941), Ernest Bevin, the minister of labour and national service, took power to prevent workers leaving their jobs and to fine them for absenteeism and ill-discipline. Bevin made increasing use of powers to direct labour where it was most needed, such as the mines and construction sites. In essence, these were measures of industrial conscription and statutory intervention, to fix minimum wages and conditions in poorly organised industries, and the measures extended rapidly during the war. ${ }^{25}$

Also in South Africa, the requirements of war necessitated changes in the methods of administration. This resulted in considerable industrial expansion. Like all belligerents, the Smuts cabinet armed the state under the War Measures' Act No. 13 of 1940. Mobilising an economy in support of a war effort requires significant state intervention in the market economy. South Africa's economy was transformed by war-related industrialisation and a sharp increase in government expenditures and revenues. But, unlike many other countries, South Africa had the gold to finance the war effort. In 1939, the country produced a third of the world's gold output and was able to maintain and expand gold production throughout the war years despite labour shortages. This, together with the increase in the price of gold over the period, largely covered the costs of the war for South Africa. The state helped itself to a range of arbitrary powers, including wage and price control, distribution under licence, the provision of subsidies for strategic industries, powers to control supplies and strategic minerals - such as gold in particular, - and means to curb industrial unrest. ${ }^{26}$

The war and the subsequent War Measures' Acts would severely restrict the activities of the NRT and the anti-war miners' faction. ${ }^{27}$ For example, under the War Measures' Act No. 9 of 1942, strike action by white workers was prohibited, and compulsory arbitration of industrial disputes was introduced. ${ }^{28}$ Initially, the MWU executive dissociated itself from the decision by the South African Trades and Labour Council (a labour federation to which the MWU was affiliated) to support Smuts's war effort, but in May 1940, this decision was reversed and the executive announced that henceforth the union would support the government's war policy. ${ }^{29}$ 
The pro-Nationalist Reformers reacted sharply to the reversed decision, arguing that the MWU executive associated itself with the imperial government's policy while forsaking the miners' interests for foreign interests. The decision created polarisation between anti-war Afrikaner miners and Englishspeaking workers and stimulated further discrimination against pro-Nationalist Afrikaners in union ranks. ${ }^{30} \mathrm{JA}$ van den Bergh, the MWU president, was accused by the Reformers of being the key role player in the union's decision to change its position towards supporting the war effort. The Reformers would fight him until the MWU was thoroughly reformed to serve the interests of the workers only. ${ }^{31}$ Shortly afterwards, the Reformers announced a campaign to thwart any effort to introduce the so-called Red Oath in the MWU. The Red Oath was a government initiative to induce civilians to do active duty in the war. Simon Schoeman, a Reformer, accused the MWU executive of collaborating with the Union Defence Force to lure Afrikaner miners into signing the Red Oath under the pretence that key positions in the union would go to those who did so. ${ }^{32}$

However, the Reformers' resolve to oppose the pro-war faction within the MWU politically was stopped when Colin Steyn, Smuts's minister of justice, and Walter Madeley, an SALP ally who was appointed to the prime minister's war cabinet as minister of labour, decided to amend Clause 135 of the MWU constitution to stipulate that no elections for the MWU executive would be held during the war and up to six months after the cessation of hostilities. This amendment was implemented under Article 1 of the War Measures' Act No. 29 of 1940, as promulgated by Smuts. The Act made special provision, inter alia, for a moratorium in certain circumstances for the protection of persons on military service. ${ }^{33}$ The rationale for Steyn and Madeley's decision was that, since more than 7000 miners had already been called up for active service by 1940, it would be unfair towards them to hold any elections within the MWU during their absence. Since, at the time, the South African economy revolved in essence around gold production, it was argued that any political labour struggles in the strategically important gold mine industry could disrupt the optimal production of gold and therefore affect the state's war effort negatively. ${ }^{34}$

Naudé, however, questions the credibility of the reasons given for the moratorium on MWU political activities during the war, and argues that members of other unions were also called up for military service although no suspension of elections took place in those unions. In the light of the fierce struggle for hegemony in the MWU between the UP - SALP faction on the one hand, and the pro-NP Reformers on the other in the years prior to the outbreak of World War II, Naudé's argument could have some merit. Before the suspension of elections in the MWU under the War Measures' Act No. 29 of 1940, there were indications that the Reformers could take over the executive in a subsequent election for officials. Non-loyal control of a union in a strategically important industry during wartime could be bad for Smuts - a situation he wanted to avoid at all costs. Furthermore, a reduction of parliamentary seats took place in 1942 as a result of changing demographic patterns and increasing Afrikaner urbanisation. Six new seats were awarded to the Witwatersrand, which increased the possibilities for success of pro-NP candidates in any trade union or general election in that region. ${ }^{35}$

Prior to the implementation of the War Measures' Act No. 29 of 1940, the political struggle for control of the MWU took a dramatic turn when Charles Harris, the general secretary, was assassinated in June 1939 by a young deranged Afrikaner miner not connected with the Reformers. ${ }^{36}$ In the subsequent elections for a new general secretary, held in March 1940, the MWU executive resorted to ill-concealed ballot rigging. When the Reformers threatened to react to this move with a wartime strike, government was compelled to intervene and appoint a commission of inquiry. The commission was chaired by LP van 
Zyl Ham, the secretary for mining. The commission acknowledged the existence of corrupt practices and made some recommendations for modification of these practices. These included the removal from office and prosecution of Jan Kukkuk, the MWU's candidate for general secretary who initially succeeded over JS de Wet, the Reformers' candidate, in the fraudulent elections. Kukkuk was replaced by Bertie Brodrick, one of the union's existing executive members. ${ }^{37}$

The committee's findings put Brodrick in a dilemma. Although he acknowledged that the MWU had made mistakes in the past and declared the union's willingness to amend their ways the statutory situation during the war complicated matters. The MWU's amended constitution, which under War Measures' Act No. 29 of 1940 prohibited any reforms in terms of the executive for the duration of the war and up to six months after the cessation of hostilities, put the union in a Catch 22 situation. For the time being, essential reforms in the MWU would be postponed to some indefinite future period. However, this status quo created a fertile environment for cropped-up grievances against the MWU executive to accumulate further and encouraged the Reformers to continue their protest actions. ${ }^{38}$

\section{The MWU and the mining strikes of 1946 and 1947}

According to De Kock, the implementation of war measures in the MWU during World War II was a prime catalyst for stirring growing discontent among miners. The amendment of the MWU constitution without approval by the rank and file union members through voting not only prevented their say in the running of the union's affairs, but also violated the closed shop principle. Two factors would force the miners to resort to the strike weapon. Firstly, the Department of Labour was unable to honour its promises to bring the MWU house in order by permitting an election for a new executive after the war. Secondly, negotiations in this regard with Gen. Smuts, the prime minister since February 1946, proved to be fruitless. ${ }^{39}$ On recommendation of the Van Zyl Ham Commission of Inquiry, certain changes were made, inter alia, the replacement of Kukkuk with Brodrick as general secretary. However, the old executive, which dated from the Harris administration, was firmly intact because of the war measures. These measures not only suspended the election of shaft stewards, but also empowered the status quo executive to appoint all board members and paid officials undemocratically. ${ }^{40}$ Protected by the war measures, it was this executive who constantly refused to re-amend the MWU constitution to provide for immediate elections in the union. ${ }^{41}$

Brodrick was unpopular and regarded by many as dictatorial. In 1943, he negotiated a wage increase of $30 \%$ on behalf of the MWU with the Gold Producer's Committee (GPC) - the executive of the Chamber of Mines. This was, however, withdrawn rapidly in return for an annual payment to the union of $£ 100000$ for five years by the GPC, for housing and other cooperative schemes to be agreed upon between the GPC and the MWU. The MWU leadership agreed to submit no further wage demands unless "existing conditions should change very materially". Co-operative farms purchased with this grant were rapidly bankrupted while membership fees doubled in 1943. An insurance scheme started by the union to support the widows of deceased miners never realised any claims. ${ }^{42}$ Naturally, the miners were outraged by the lack of wage increases and became incensed at what was regarded as the MWU's capitulation to mining capital - a situation aggravated by the prohibition of elections for a new union executive under the War Measures' Act No. 29 of 1940, which had still not been repealed by 1946. Consequently, the seething discontent among the miners erupted in a general strike in $1946 .{ }^{43}$ 
By this time, it was also evident that the Reformers were no longer the only miners' organisation prepared to take on the MWU executive committee. The Reformers were only one of several groups of miners who agitated against the MWU executive. Many ex-soldiers and war volunteers also joined the strike because in principle they were opposed to the corruption of the MWU administration. The exsoldiers in particular were dissatisfied because they were being pressed to pay their union dues in arrears for almost forty months during the war, despite the fact that soldiers who had been on active duty were supposed to be exempted from union fees for the period of their service. ${ }^{44}$ During the 1946 strike, a socalled Protesting Miners' Committee (PMC) was also established. Although many protesting miners shared the Reformers' dissatisfaction with the MWU executive, they did not want to associate themselves with the Reformers. The Van Zyl Ham Commission of Inquiry concluded that the Reformers' motives were harmful to the interests of the miners and the mining industry and that they were being driven by interest outside of the industry, such as the NRT. ${ }^{45}$ Indeed, a former leader of the Reformers, Simon Schoeman, testified before another commission of inquiry into the affairs of the MWU in 1946, chaired by Brig. E Williamson, "The miners have been dissatisfied, but if the sinews of war were not supplied and instructions were not given by these people [the NRT], very few miners would have done anything on their own". 46

At first Smuts appeared to be disinterested in the miners' grievances over their undemocratic executive and regarded it to be a domestic dispute in which he would not like to meddle. However, the paralysing effect of the strike on the gold mining industry and the South African economy in general forced him to intervene. Although negotiations vacillated while the strike spread to all the gold mines on the Witwatersrand, a settlement was finally reached on 22 March 1946. The terms of settlement stipulated, inter alia, that an election for all officials in the MWU management would be held under the supervision of the Department of Labour between 1 May and 1 June 1946. The government also agreed to yet another commission of inquiry - the so-called Williamson Commission. ${ }^{47}$ The agreement was signed between the strikers and government only as the MWU executive remained intransigent to any change of its status quo. Therefore, the settlement was proclaimed by the War Measures' Act No. 13 of 1946, as amended by the War Measures' Act No. 26 of 1946. ${ }^{48}$ In the meantime, various dissatisfied miners within MWU ranks, including members of the PMC, ex-Reformers and a so-called action committee, reorganised themselves into the United Mine Workers' Committee (UMC) with Daan Ellis, a pro-NP miner, as secretary. ${ }^{49}$

The Williamson Commission's terms of reference were to investigate and report on the affairs of the MWU since the conclusion of the Van Zyl Ham Commission's investigation until March 1946. The Williamson Commission's scope also included supervision of the execution of duties and functions of the MWU executive until the publication of the commission's report, to take control of the union's administrative functions, should the executive act unconstitutionally, and to supervise elections for a new executive. ${ }^{50}$ However, while the commission was still conducting its inquiry, events took an unexpected turn when Bertie Brodrick was discharged from his position as general secretary by a MWU general council meeting. As a result, thirteen of the nineteen members of the MWU's executive committee also resigned. Apparently Brodrick's autocratic behaviour and his poor handling of the MWU's affairs had taken their toll. ${ }^{51}$ Consequently, and in accordance with its powers, the Williamson Commission appointed an interim executive with JLP (Basie) Botha as acting general secretary. The interim MWU executive would act under supervision of the commission. Under the terms of the war measures, the 
interim executive would be disbanded within thirty days after the proposed elections for a new executive had been concluded. ${ }^{52}$

According to De Kock, the report of the Williamson Commission brought to light not only damning evidence of financial chaos and mismanagement, general maladministration and undemocratic action by the executive, incompetence of officials and corruption, but it comprised also criticism of government's conduct towards the MWU since the implementation of the War Measures Acts. De Kock argues that the decision by Smuts's two wartime ministers, Colin Steyn and Walter Madeley, to amend Clause 135 of the MWU constitution so that it would stipulate that no elections for the MWU executive would be held during the war and up to six months after the cessation of hostilities under Article 1 of the War Measures' Act No. 29 of 1940, gave undue powers to a corrupt MWU executive, which caused much strife within the union. As minister of labour, Madeley had access to the relevant documents, which made him realise that things had gone drastically wrong in the MWU. However, for the sake of domestic stability during the war, he did not interfere to improve the situation. ${ }^{53}$

When elections for a new post-war MWU executive committee were finally set for July 1946, there was intensive lobbying for votes. On the one side were Brodrick and his supporters - on the other, the UMC. But when election irregularities among shaft stewards led to disputes and the Williamson Commission's arbitration of the matter thwarted the UMC's chances of obtaining a majority vote in the MWU's general council (the union's supreme authority), another strike broke out in January 1947, eventually involving 11000 miners on 21 gold mines. ${ }^{54}$ The struggle for control of the MWU intensified and assumed an increasingly political character. While certain legal aspects of the War Measures' Acts were still in force concerning the administration of the MWU, the question of union control degenerated into a constitutional conundrum between the interim executive who wanted to retain control and the UMC who wanted to get rid of the "remnants" of the Brodrick regime. ${ }^{55}$

When Smuts indicated that the government had no plans to interfere in the MWU's domestic disputes, the UMC felt obliged to approach NP members of parliament (MPs) for assistance in solving the issue and it became clear that the party's political influence would play an important role in the strike. The Nationalists blamed the origins of the 1947 strike on Colin Steyn's original approval of the extraordinary war measures whereby all elections in the MWU had been suspended temporarily. They blamed the UP government's refusal to mediate in the strike as being discrepant to its own War Measures' Acts, which the NP regarded as direct interference in the union's affairs. The NP also demanded that the government honour its promises to get the MWU's house in order. ${ }^{56}$ Various prominent NP leaders - such as DF Malan, JG Strijdom and CR - Swart gave their unconditional support to the strikers. They also received moral support from Afrikaner churches and farmers as well as Afrikaner cultural organisations such as the Federasie van Afrikaanse Kultuurvereniginge, the Reddingsdaadbond, the Blankewerkersbeskermingsbond and the Afrikaner Broederbond. Not surprisingly, the UP and its press organs began to regard the strike as rather a pro-NP political struggle. ${ }^{57}$

After intensive negotiations the strike was called off on 11 March 1947 when agreement was reached between the UMC, the MWU and the Mining Unions' Joint Committee (a body which represented other artisans and mechanics employed by the mines).$^{58}$ Also in 1947 the still prevailing War Measures Acts were finally repealed by Act No. 30 of 1947 (the War Measures' Repeal Act). ${ }^{59}$ The strike of 1947 had substantial repercussions. Besides support by NP leaders and Afrikaner civil institutions, there was overwhelming support for the strike, especially from Afrikaner miners, but also from Englishspeaking miners. According to De Kock, the success of the strike was a resounding moral victory for the 
UMC. The pro-NP grouping succeeded in swaying public sentiment a step further away from the UP government and toward putting Afrikaner nationalism on a more sound footing in the working-class constituencies of the Witwatersrand. ${ }^{60}$

\section{Epilogue of the struggle for political hegemony in the MWU}

\subsection{The so-called Gleisner disclosures}

The terms of settlement of the 1947 strike stipulated, inter alia, that a new commission of inquiry would finally be authorised to conduct and supervise the election of MWU shaft stewards, which had been postponed and prolonged for a long time as a result of the war measures. The commission was chaired by ST Goetzsche, a Johannesburg magistrate. ${ }^{61}$ By August 1947, the MWU executive also succeeded in finally amending the union's constitution to enable the Goetzsche Commission to supervise its elections. By using obstructionist tactics, the UMC, however, tried to question the validity of the commission. This was done in order to curtail the powers of the MWU executive, for which the Goetzsche Commission acted as supervisory proxy, to exercise as little as possible direct influence on the intended election for shaft stewards. ${ }^{62}$

However, events took a whole new turn when Jan Gleisner, a journalist and former UP henchman whose guilty conscience compelled him to do so, revealed a plot of covert co-operation between prominent members of the UP, pro-UP members of the MWU executive and even members of the Goetzsche Commission. Gleisner's sensational disclosures were revealed by the NP during the parliamentary session of March 1948 and a complete version was also published in Die Burger, an NP organ. ${ }^{63}$

Gleisner revealed secret plans forged by the UP to keep white miners subservient to party interests. According to Gleisner, Basie Botha, the pro-UP acting general secretary and MC Basson of the MWU executive, received orders to cooperate with one JT Bester, the UP contact within the union. In this way, the UP tried to secure the position of the pro-UP union executive and to prevent the NP from making any inroads in terms of political allegiance in the MWU. ${ }^{64}$ The Mineworker, the official MWU organ, was utilised even as early as the 1943 general elections to propagate overt support for the candidates of the UP - SALP alliance in so-called working-class constituencies. ${ }^{65}$ Gleisner also revealed that UP funds had been allocated to buy votes from MWU designates to the union's general council meeting. An even bigger shock was his disclosure that the pro-UP Botha faction in the executive was supported financially by the Chamber of Mines and that this money was deposited in a trust fund. The purpose of these slush funds was to sow dissention within the ranks of the UMC so that the pro-UP faction could win the elections for control of the MWU executive. The end result of the interference of government officials in the mine workers' dispute, as well as the co-operation between the Botha group and the Goetzsche Commission to keep the miners subservient to UP interests, was that the process of eventually establishing a democratically elected MWU executive became an unsavoury, drawn-out affair. In this regard, the stipulations of the war measures thus became a handy tool. ${ }^{66}$ 


\section{$5.2 \quad$ The elections of 1948}

With the impending general elections of May 1948 in mind, the NP immediately seized the opportunity posed by the Gleisner disclosures to bring the UP government into disfavour and to wean mine workers' votes away for the UP. The disclosures ignited the smouldering public emotions finally against the Smuts government, which contributed to the NP's victory. According to Naudé and De Kock, the result of the 1948 general election was also a reflection of the white miners' disgruntlement with the UP government's handling of their affairs. Their support further enabled the NP to conquer six critical so-called mining constituencies on the Witwatersrand - Randfontein, Krugersdorp, Maraisburg, Kempton Park, Germiston and Northeast Rand which, in turn, contributed to Smuts's election defeat. ${ }^{67}$

The election for new MWU shaft stewards was scheduled for 5 May 1948. In order to strengthen their ranks, the PMC and the UMC decided to set aside their differences, and in March 1948, they amalgamated into a new structure, the United Miners (UM) to fight the elections. The old pro-UP executive obtained an almost complete victory for control of the MWU executive, but still the saga did not end. Paul Couzyn, a colleague of Albert Hertzog who also acted on behalf of the NRT, investigated the disenfranchisement of approximately 80 leaders of the 1947 strike, who were still unemployed by the time of the MWU executive elections. The MWU constitution stipulated that only miners in active service of the mining industry at election time could vote and were eligible for election. This excluded the 80 unemployed miners from participation in the MWU elections of May 1948. For the umpteenth time the matter had to be settled in court when Couzyn's investigations concluded that the Goetzsche Commission was still acting according to the stipulations of the War Measures' Act No. 13 of 1946 and the War Measures' Act (Amended) No. 26 of 1946, even though the validity of the Acts were null and void by 1948. Therefore, the court ruled in June 1948, that the MWU elections, as well as the nomination of all executive members by the general council, were once again invalid. ${ }^{68}$

A final obstacle for the UM was that the court could not alter the position of Basie Botha, the MWU acting general secretary. Under the MWU constitution, Botha, as the last remaining member of the old executive, was empowered to select an executive of his own choice. In order to prevent such an undemocratic move, the UM held discussions with the new NP Minister of Labour, Ben Schoeman. Through Schoeman's mediation, the two opposing factions within the MWU were finally able to reach an agreement by the end of June 1948. It was agreed that an election for all office bearers in the MWU would be scheduled for 1 November 1948 to be supervised by the Department of Labour. Amendments to the MWU constitution, clearing all constitutional obstacles to having free and fair elections for union officials, were also ratified with this agreement. ${ }^{69}$ In his personal diaries, Albert Hertzog acknowledged that the NP government's pressure on the old MWU executive had created the opportunity for a new executive to come to power. ${ }^{70}$

Eventually, six months after the NP's victory in the 1948 general election, the UM, consisting of a strong core of pro-NP ex-Reformers, finally gained control of the MWU executive. In the November elections for shaft stewards, the UM won 187 seats out of 195, and 35 UM members out of a total of 49 were also elected to the MWU's general council. Paul Visser became the new MWU president and Daan Ellis, an ex-Reformer and NP supporter, was elected as the union's new general secretary. ${ }^{71}$ 


\section{Conclusion}

The long struggle for control of the MWU executive, involving strife in union ranks, numerous court actions and three official commissions of inquiry, can be attributed to a number of causes. On the one hand, the government's incorporation, institutionalisation and bureaucratisation of white unions within state structures through industrial legislation succeeded to stabilise the white labour force and bring peace to the mining industry. On the other hand, the bureaucratisation of its officials made the MWU susceptible to maladministration, corruption and dictatorial behaviour by opportunistic individuals. Matters were complicated when the bitter ensuing struggle for control of the executive became entangled in the struggle for political hegemony between the NP and the UP and the culmination of Afrikaner nationalism. This situation was aggravated even more by the outbreak of World War II and the implementation of the War Measures' Acts. In fact, the war measures contributed to the constitutional impasse regarding democratic reform of the MWU's constitution and the struggle for control of its executive. This eventually became a protracted process, which dragged on for twelve years. In terms of politics and elections, at national and union level, the war and its war measures had a profound effect. Many historians concur that at national level, the disruptions and irritations brought about by the war effort, the Smuts government's wartime controls over food distribution, South Africa's entrance to the war on a split vote, the inefficiency of government's demobilisation scheme and housing programme for ex-soldiers, all contributed to the UP's fall from power. ${ }^{72}$

In terms of the MWU, the UP government's apparent bias towards solving the union's constitutional problems, which were partially affected by the War Measures' Acts, also backfired. On the one hand, government handled the MWU's problems in a manner to gain political expediency among mining constituents. This factor, as well as Smuts's apparent unwillingness to intervene boldly in order to end the protracted strife in miners' ranks, extended the efffect and validity of the War Measures' Acts to three years beyond the cessation of hostilities. In the end, however, it cost the UP six crucial mining constituencies on the Witwatersrand as well as a loyal MWU executive in the elections of 1948. The effect of the War Measures' Acts during World War II on the MWU, therefore, serves as a good example of the profound political influence of war on society.

1 Approximately seventeen acts relating to war measures and its legal consequences were promulgated by Parliament between 1940 and 1947: War Measures' Act No. 13 of 1940; Defence Special Pensions and Moratorium (War Measures') Act No. 29 of 1940; War Measures' (Amendment Act) No. 32 of 1940; War Damage Insurance Act No. 21 of 1941; Active Service Voters' Act No. 37 of 1941; War Pensions Act No. 45 of 1941; War Measures' Act No. 9 of 1942; War Damage Insurance Amendment Act No. 25 of 1942; War Pensions Act No. 44 of 1942; War Service Voters' Act No. 34 of 1943; Soldiers and War Workers' Employment Act No. 40 of 1944; Military Service Act No. 2 of 1945; War Measures' Act No. 13 of 1946; War Measures' Act (Amended) No. 26 of 1946; War Pensions Laws Amendment Act No. 58 of 1946; War Pensions Laws Amendment Act No. 17 of 1947 and the War Measures' Repeal Act No. 30 of 1947.

2 JM Winter (ed.). War and economic development: Essays in memory of David Joslin. Cambridge: Cambridge University Press, 1975, 1.

3 AM Grundlingh. Fighting their own war: South African blacks and the First World War. Johannesburg: Ravan Press, 1987, 2.

$4 \quad$ See, for example, Winter op. cit., and J Hinton. Labour and socialism: A history of the British Labour Movement 1867 - 1974. Amherst: University of Massachusetts Press, 1983, 96 - 118.

$5 \quad$ M Stein. "Max Gordon and African Trade Unionism on the Witwatersrand, 1935 - 1940". In E Webster (ed.). Essays in southern African labour history. Johannesburg: Ravan Press, 1978, 143 - 157. 
Y Albertyn. "Upsetting the applecart: Government and food control in the Union of South Africa during World War Two c. 1939 - 1948". Unpublished MA thesis, Stellenbosch University, Stellenbosch, 2014.

D Ticktin. "The origins of the South African Labour Party, 1888 - 1910". Unpublished PhD thesis, University of Cape Town, Cape Town, 1973, 113 - 114; E Gitsham \& JF Trembath. A first account of labour organisation in South Africa. Durban: EP \& Commercial Printing, 1926), 28, 66; RK Cope. Comrade Bill: The life and times of WH Andrews, workers' leader. Cape Town: Stewart Printing, 1943, 89, 110 - 111; IL Walker \& B Weinbren. 2000 Casualties: A history of the trade unions and the labour movement in the Union of South Africa. Johannesburg: SATUC, 1961, 22, 42; E Katz. A trade union aristocracy: A history of white workers in the Transvaal and the General Strike of 1913. Johannesburg: African Studies Institute, 1976, 152, 226, 252.

AG Oberholster. Die mynwerkerstaking, Witwatersrand 1922. Pretoria: RGN, Pretoria, 1982, 56 - 191; W Urquhart. The outbreak on the Witwatersrand March 1922. Johannesburg: Hortors, 1922, 33, 74 - 96; J Krikler. The Rand Revolt: The 1922 insurrection and racial killings in South Africa. Jeppestown: Jonathan Ball, 2005.

FA Johnstone. Class, race and gold: A study of class relations and racial discrimination in South Africa. Lanham, MD: University Press of America, 1976, 150, 156, 166 - 167; BJ Liebenberg \& SB Spies (eds). South Africa in the 20 th century. Pretoria: JL Van Schaik, 1993, 180 - 182; TRH Davenport. South Africa: A modern history. Johannesburg: Macmillan, 1987, 287, 531 - 534.

RH Davies. Capital, state and white labour in South Africa 1900-1960. Atlantic Highlands, NJ: Humanities Press, 1979, 179 - 181, 195 - 198, 231; D Yudelman. The emergence of modern South Africa: State, capital and the incorporation or organized labor on the South African gold fields, 1902 - 1939. Westport: Greenwood Press, 1983, 9, 114 - 115, 186, 208 - 233.

L de Kock. "Die stryd van die Afrikaner in die Suid-Afrikaanse Mynwerkersunie aan die Witwatersrand, 1936 - 1948". Unpublished MA thesis, RAU, Johannesburg, 1983, 10; L Naudé. Dr A Hertzog, die Nasionale Party en die mynwerkers. Pretoria: NRT, 1969, 22 - 24.

See De Kock op. cit., chs 1 - 4 and Naudé op. cit., 1 - 71, 96 - 126.

E Stals (ed.). Afrikaners in die Goudstad. Deel I: 1886 - 1924. Cape Town: HAUM, 1978, 36, 40, 86; D Ticktin. "The war issue and the collapse of the South African Labour Party". South African Historical Journal 1. November 1969, 60.

L Salomon. "The economic background to the revival of Afrikaner nationalism". In J Butler (ed.). Boston University papers in African history, Vol. 1. Boston, MA: Boston University Press, 1964, 232, 238.

Naudé op. cit., 18 - 19.

Ibid., 27.

Ibid., 10, 18, 27; H van Aswegen \& L de Kock. "Afrikanermynwerkers en die Mynwerkersunie, 1936 1948, 1”. Historia, 32 1. May 1987, 22.

South African National Archives, Pretoria (hereafter NASA), Mine Workers' Union Inquiry Commission 1940-1941 (hereafter K6), Band 2, Verbatim reports, Minutes of evidence, Vol. 5: MWU executive testifies (4 November 1940), 308, 314, 316, 321 - 322, 367 - 370; Ibid., Vol. 10: JS de Wet testifies (13 November 1940), 667; Ibid., Band 3, Verbatim reports, Minutes of evidence, Vol. 25: IL Walker testifies (12 December 1940), 2109 - 2113, 2121, 2124.

Van Aswegen \& De Kock op. cit., 22 - 23; Naudé op. cit., 16 - 27; J Albertyn (ed.). Die stadwaartse trek van die Afrikanernasie. Referate en besluite van die Volkskongres. Johannesburg: Volkskongreskomitee, 1947, 8, 97.

NASA, K6, Band 4, File VI: Final reports, Findings \& recommendations, 2 - 7, 14.

Van Aswegen \& De Kock op. cit., 27 - 28; Naudé op. cit., 41 - 42.

Transvaal Archives Depot, Pretoria (hereafter TAD), A1731, SJ Botha Collection, Vol. 4: Die stryd om die vakbonde. Persoonlike herinneringe van DBH Grobbelaar, 1; Naudé op. cit., 50 - 57; H van Aswegen \& L de Kock. "Die Hervormingsorganisasie in die Mynwerkersunie, 1937 - 1948, II". Historia 32 2. September 1987,1 .

NASA, K6, Band 2, Vol. 9: SS Schoeman testifies (12 November 1940), 571 - 572; Ibid., Vol. 10: JS de Wet testifies, 686 - 687; Ibid., Vol. 12: JS de Wet testifies (18 November 1940), 823 - 824; Ibid., Band 4, File VI: Final reports, Findings \& recommendations, 17 - 20 and Appendix D, 1 - 2; Van Aswegen \& De Kock, "Die Hervormingsorganisasie... op. cit., 2.

Davenport op. cit., 328 - 329.

Hinton op. cit., 163. 
N Nattrass. "Economic growth and transformation in the 1940s". In S Dubow \& A Jeeves (eds). South Africa's 1940s: Worlds of possibilities. Cape Town: Double Storey Books, 2000, 20 - 21; Davenport op. cit., 330.

TAD, A1731, SJ Botha Collection, Vol. 4: Die stryd om die vakbonde. Persoonlike herinneringe van DBH Grobbelaar, 6.

Nattrass op. cit., 28, 31.

NASA, K6, Band 2, Vol. 12: CC Hudson testifies (18 November 1940), 846; "Mynwerkers se bestuur teen oorlog". Die Transvaler. 20 September 1939; "Hervormingsorganisasie hernu stryd". Die Transvaler. 24 May 1940.

De Kock, "Die stryd van die Afrikaner..." op. cit., 131.

"Nuwe stryd dreig in geledere van Randse mynwerkers". Die Vaderland. 19 July 1940; "Hervormers hernu stryd". Die Transvaler, 24 August 1940.

"Mynwerkers voor krisistyd moet saamstaan". Die Transvaler. 29 August 1940.

Naudé op. cit., 176 - 177; Statutes of the Union of South Africa 1939 - 40. Cape Town: Government Printer, 1940, $540-560$.

Naudé op cit., 177; T Dunbar Moodie. The rise of Afrikanerdom: Power, apartheid and the Afrikaner civil religion. Berkeley, CA: University of California Press, 1975, 171.

Naudé, Dr A Hertzog, pp. 173-176; De Kock, "Die stryd van die Afrikaner", pp. 134-135.

"Charles Harris shot outside his office". The Mineworker. June 1939, 126-127; Naudé op. cit., 129.

NASA, K6, Band 4, File VI: Final reports, Findings \& recommendations, pp. 1 - 10, 58 - 73; Naudé op. cit., 136-145.

"Kameraad B.B. Broderick, algemene sekretaris, antwoord op die kommissie se verslag". The Mineworker. June 1941, 3, 6; "Vrede! Met wie". The Mineworker. July 1941, 37, 39; De Kock, "Die stryd van die Afrikaner..." op. cit., 167.

De Kock, "Die stryd van die Afrikaner..." op. cit., 170, 179 - 180.

NASA, Commission of Enquiry 1946-48 (hereafter K145), Band 3, File III, Memoranda: Mine Workers' Union, n.d., 1; TAD, A1731, SJ Botha Collection, Vol. 7, SAMWU 1952 Verslag, Deel B: Mnr Gleisner se opsoming in verband met die Kommissie van Ondersoek, 29 April 1952, 4.

NASA, K145, Band 3, File III, Memoranda: Mine Workers' Union, n.d., 1; "Miners' executive will consider strike position today". The Rand Daily Mail. 18 March 1946.

NASA, K145, Band 1, Vol. 1: Minutes, p. 5; Ibid., Band 3, File III: Mine Workers Union, p. 1 and Memorandum of Agreement; NASA, A2, JG Strijdom Collection, Vol. 78: Mynwerkersgeskil, 88; TAD, A1731, SJ Botha Collection, Vol. 7, SAMWU 1952 Verslag, Deel B, 4 - 5, 8; Naudé op. cit., 202 - 203.

NASA, K145, Band 3, File III: Mine Workers Union, 1; NASA, A2, JG Strijdom Collection, Vol. 78: Mynwerkersgeskil, 88, 97; TAD, A1731, SJ Botha Collection, Vol. 7: SAMWU Verslag, Deel B, 8; Naudé op. cit., 209; Davenport op. cit., 342.

De Kock, "Die stryd van die Afrikaner..." op. cit., 178-179.

See NASA, K6, Band 4, File VI: Final reports, Findings \& recommendations, 7; TAD, A1731, SJ Botha Collection, Vol. 7: SAMWU Verslag, Deel B, 5, 8 - 9; NASA, K145, Band 2, Vol. 2: Minutes of the 82 ${ }^{\text {nd }}$ meeting, 1 - 2; Van Aswegen \& De Kock, "Die Hervormingsorganisasie..." op. cit., 7, 9.

Quoted by De Kock, "Die stryd van die Afrikaner..." op. cit., 158.

NASA, K145, Band 1, Minute book, Vol. 1: Minutes of the $22^{\text {nd }}$ meeting, 7 May 1946, 5; Ibid., Band 3, File III, Memoranda: Mine Workers' Union, n.d., 1 and Terms of settlement of gold mining strike, 22 March 1946, 1 - 2; Naudé op. cit., 211; De Kock, "Die stryd van die Afrikaner..." op. cit., 182 - 183.

NASA, K145, Band 1, Minutes of meetings and verbatim reports, Minute book Vol. 1: Minutes of the 22nd meeting, 7 May 1946, 5; Ibid., Band 3, File III, Memoranda: Mine Workers' Union, n.d., 1 and Terms of settlement of gold mining strike, 22 June 1946, 1 - 2; De Kock, "Die stryd van die Afrikaner..." op. cit., 180 - 184; J Lang. Bullion Johannesburg: Men, mines and the challenge of conflict. Johannesburg: Jonathan Ball, 1986, 376.

NASA, K145, Band 1, Minute book Vol. 1: Minutes of the $44^{\text {th }}$ meeting, 11 June 1946, 2; Ibid., Band 2, Minute book Vol. 2: Minutes of the 82 ${ }^{\text {nd }}$ meeting, 24 April 1947, 1 - 2; Naudé op. cit., 205; De Kock, "Die stryd van die Afrikaner..." op. cit., 174, 184 - 186, 189.

De Kock, "Die stryd van die Afrikaner..." op cit., 187.

NASA, K145, Band 1, Vol. 1: Minutes of the $18^{\text {th }}$ meeting, 1 - 2; Ibid., Band 3, File III: Memorandum, 1; NASA, A1731, SJ Botha Collection, Vol. 7: SAMWU Verslag, Deel B, 7 - 8; UG 36, 1946: Report of the 
Mine Workers' Union Commission, p. 4; Van Aswegen \& De Kock, "Die Hervormingsorganisasie...," op cit., 9.

NASA, A1731, SJ Botha Collection, Band 7, SAMWU 1952, Verslag, Deel B: Mnr Gleisner, 8.

De Kock, "Die stryd van die Afrikaner..." op. cit., 195. See also UG 36, 1946: Report of the Mine Workers' Union Commission.

NASA, K145, Band 2: Minutes of the $65^{\text {th }}$ meeting, $7-11$ and $66^{\text {th }}$ meeting, 1; NASA, A2, JG Strijdom Collection, Vol. 78: Mynwerkersgeskil, 81 - 83, 90, 98; Instituut vir Eietydse Geskiedenis, UV, Bloemfontein (hereafter INEG), PV 451, JAM Hertzog Collection, File no. 1/266/8/1: D Ellis: Verslag van Werksaamhede 1947, 4 - 5; Ibid., Jaarverslag 1947, p. 2; Lang op. cit., 377; Van Aswegen \& De Kock, "Die Hervormingsorganisasie...," op. cit, 10.

NASA, K145, Band 2, Minutes of meetings and verbatim reports, Minute book, Vol. 2: Minutes of the $63^{\text {rd }}$ meeting, 29 July 1946, 1 - 2; Ibid., Minutes of the $65^{\text {th }}$ meeting, 9 August 1946, 7 - 11; Ibid., Minutes of the $66^{\text {th }}$ meeting, 10 August 1946, $1-2$.

De Kock, "Die stryd van die Afrikaner..." op. cit., 204 - 212; E Stals (ed.). Afrikaners in die Goudstad. Deel 2: 1924 - 1961. Pretoria: HAUM, 1986, 78; J Simons \& R Simons. Class and colour in South Africa 1850 - 1950. London: IDAAF, 1983, 567.

De Kock, "Die stryd van die Afrikaner..." op. cit., 209 - 216; Naudé op. cit., 223 - 227; Stals, Afrikaners in die Goudstad, Deel II...op. cit., 78; Simons \& Simons op. cit., 567; AN Pelzer. Die AfrikanerBroederbond: Eerste 50 jaar. Cape Town: Tafelberg, 1979, 153; INEG, PV 451, JAM Hertzog Collection, File no. 4/1/208: Dagboek: Februarie 1947, 132.

NASA, K145, Band 3, File III, Memoranda: Minutes of a meeting of the MUJC, 21 April 1947, 5 - 11; Ibid., Mine Workers' Union, n.d., 2 - 3; Leader article. The Mineworker. March 1947, 3; De Kock, "Die stryd van die Afrikaner..." op. cit., 221; Naudé op. cit., 229; Stals, Afrikaners in die Goudstad, Deel II...op. cit., 78; A Hepple. Trade unions in travail. Johannesburg: Prompt Printing, 1953, 40.

Statutes of the Union of South Africa 1946 - 47. Cape Town: Government Printer, 1947, 278.

INEG, PV 451, JAM Hertzog Collection, File no. 1/266/8/1: D Ellis: Verslag van Werksaamhede 1947, 5;

Ibid., Jaarverslag 1947, 5 - 6; De Kock, "Die stryd van die Afrikaner..." op. cit., 222 - 223.

NASA, Archives of the Treasury, Vol. 5714, File no. 33/487, Mine Workers' Union Commission of Enquiry 1946: Secretary for Labour - Secretary to the Treasury, 26 April 1947; Ibid., Secretary for Labour - Secretary to the Treasury, 6 September 1947; ES Sachs. The choice before South Africa. London: Turnstile Press, 1952, 171; De Kock, "Die stryd van die Afrikaner..." op. cit., 224.

De Kock, "Die stryd van die Afrikaner..." op. cit., 226 - 229.

INEG, PV 451, JAM Hertzog Collection. File no. 1/266/8/1: Jaarverslag 1947, pp. 8 - 9; Naudé op. cit., 235 - 238; De Kock, "Die stryd van die Afrikaner...." op. cit., 230.

NASA, A1731, SJ Botha Collection, Vol 6: Nasionale Raad van Trustees 1948 - 1951, Diverse stukke i.v.m. MWU, KWU, Aksiekomitee, Gleisner-affidavit, 16 March 1948, 1 - 3, 21.

See 4 "Leader article". The Mineworker, May 1943, 4 and "Manie Cilliers, Union's Vice-President is candidate for Parliament". The Mineworker. May 1943, 5; "Mayfair Candidate". The Mineworker. July 1943, 5; "North Rand Candidate". The Mineworker. July 1943, 7; MC Basson: Wie kan die meeste belowe?". The Mineworker. July 1943, 10 - 11.

NASA, A1731, SJ Botha Collection, Vol. 6: Nasionale Raad van Trustees 1948 - 1951, Diverse stukke i.v.m. MWU, KWU, Aksiekomitee, Gleisner-affidavit, 16 March 1948, 2 - 20.

INEG, PV 451, JAM Hertzog Collection, File no. 1/266/8/1: Jaarverslag 1947, 9 - 10, Naudé op. cit., 238 239; De Kock, "Die stryd van die Afrikaner..." op cit., 237 - 238.

NASA, K145, Band 2, Minutes of meetings and verbatim reports, Minute book Vol. 2: Minutes of the $83^{\text {rd }}$ meeting, 2 May 1947, 2 - 5; Ibid., Minutes of the $84^{\text {th }}$ meeting, 29 April 1947, 2; Ibid., Minutes of the $85^{\text {th }}$

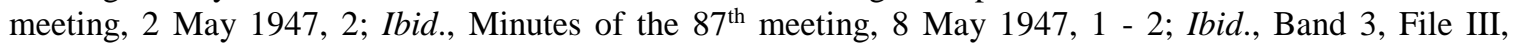
Memoranda: Mine Workers' Union, n.d., 3 - 4; Naudé op. cit., 239 - 240; De Kock, "Die stryd van die Afrikaner..." op. cit., 249 - 250.

NASA, A1731, SJ Botha Collection, Vol. 7: SAMWU 1952, Verslag, Deel B, Mnr Gleisner se opsomming i.v.m. kommissie van ondersoek, 29 April 1952, 11 - 12; MWU Archives, Pretoria, Minutes of monthly Executive Committee Meeting, 18 August 1948, 1 - 8; "Our Constitution Again Amended". The Mineworker. July 1948, 7 - 9; Naudé op. cit., 241 - 242; Stals, Afrikaners in die Goudstad, Deel II...op. cit., 78; S Patterson. The last trek: A study of the Boer people and the Afrikaner nation. London: Routledge \& Kegan Paul, 1957, 157; B Schoeman. My Lewe in die politiek. Johannesburg: Perskor, 1978, 157. 
INEG, PV 451, JAM Hertzog Collection, File no. 4/1/184: Dagboek, Januarie - Desember 1952, 4367.

Naudé op. cit., 243 - 249; "Die Nuwe Bestuur". The Mineworker. 28 January 1949, 1.

See e.g. Davenport op. cit., 354; Liebenberg \& Spies op. cit., 282 - 283; H Giliomee. The Afrikaners: Biography of a people. Cape Town: Tafelberg, 2003, 446; CFJ Muller (ed.). Vyfhonderd jaar SuidAfrikaanse geskiedenis. Pretoria: Academia, 1975, 434. 